\title{
The Influence of Fiscal Rules on the Fiscal Stability in the EU Member States
}

Ryta Iwona Dziemianowicz

Aneta Kargol-Wasiluk

University of Bialystok, Faculty of Economics and Management, Poland

\begin{abstract}
Due to the rapid increase of the budget deficit and public debt in many the EU countries after 2008, fiscal policy has faced a significant challenge for developing an appropriate tools to strengthen fiscal discipline and thereby improve the quality of public finance. Institutional mechanisms such as among others numerical fiscal rules play an important role in maintaining the fiscal discipline and support fiscal credibility of the state. Fiscal rules are most often defined as permanent constraints on fiscal policy, expressed by indicators introducing a limit for a particular fiscal aggregate, such as a budget deficit (real or structural), public debt, public expenditure or public revenue. The theoretical objective of the article is to analyze the institutional dimension of numerical fiscal rules (their type, legal basis, transparency, complexity, flexibility, adequacy and coherence). The empirical purpose, on the other hand, is to conduct a statistical analysis and to examine the relationship between the value of the fiscal rules index and the level of budget deficit and public debt in 28 Member States of the European Union. Examining the effectiveness of applied fiscal rules, at both European and national level seems to be the most valuable part of the analysis.
\end{abstract}

Keywords: fiscal policy, numerical fiscal rules, fiscal rules index, budget deficit, public debt

JEL Classification: H30, H60, H62, H63, H87

\section{Introduction}

The global financial crisis in 2008 and the resulting economic slowdown contributed to a sharp deterioration of the condition of the public finance sector in many European Union states. It turned out that the mechanism strengthening the fiscal discipline in the European Union introduced by the Maastricht Treaty (1992) and supplemented by the Stability and Growth Pact (SGP 1997) was insufficient. European fiscal rules in the form of reference values (for deficit and public debt, respectively $3 \%$ of GDP and $60 \%$ of GDP) and additional procedures included in the SGP did not protect against excessive public debt, even in countries in Euro Area.

The crisis and the increase in debt in Euro Area made it necessary to review and assess regulations that strengthen budgetary surveillance in EU states, increasing the discipline of public finance and supporting its consolidation. Such regulations include certain institutional solutions such as: fiscal rules (numerical rules), budgetary procedures (legislative rules) as well as independent fiscal institutions which form the national fiscal discipline frameworks. Implementation of most of them does not require introduction of treaty changes within the EU. Therefore, they may be complementary to regulations at the EU level.

This article focuses primarily on assessing the effectiveness of implementation of the national numerical fiscal rules within the scope of supporting fiscal stability in EU-28.

\section{Types and application of fiscal rules}

Fiscal rules are most often defined as permanent limitations on fiscal policy expressed as indicators introducing a limit for a specific fiscal aggregate, such as a (real or structural) budget deficit, public debt, expenditure or income, typically as a 
proportion of GDP. As noted by A. Schaechter et. al. (2012), the rules make it possible to implement a responsible fiscal policy and thus to achieve the fiscal stability (by reducing the pressure/ stimuli to make excessive budgetary expenditures).

According to such authors as: Kopits and Symansky (1998), the ideal fiscal rule should be:

- $\quad$ precisely defined: in order to avoid ambiguity and ineffectiveness in enforcement, the rule should be specified not only within the index limit but also within its institutional scope and non-circumvention clauses;

- $\quad$ transparent: accountable in terms of accounting, but also in terms of forecasting and management;

- $\quad$ simple: comprehensible for the legislator and the public;

- $\quad$ flexible: allowing for reaction in the event of asymmetric shocks but also containing shoot out clauses;

- $\quad$ adequate: suitable for the pursued objective;

- $\quad$ enforceable: established by higher-level legislative acts (constitutions, laws) which also contain properly defined sanctions for non-observance of the rule and the principles of their enforcement;

- $\quad$ coherent: in line with the adopted medium- and long-term fiscal strategy and economic policy;

- $\quad$ effective: supported by effective political actions.

The aforementioned characteristics of the "ideal fiscal rule" are, above all, the optimum reference point which should be sought. In fact, it is difficult to find a fiscal rule that would be built based on these principles. However, they should be treated as a specific pattern which can be used to evaluate the existing rules and which shows the direction of their possible modifications. At the same time, it should be noted that some of the desired features of the "ideal rule" mentioned above can be mutually exclusive, for example, the greater simplicity of the rule can be achieved by limiting its flexibility (Kopits, Symansky 1998).

Typically, distinguished are four types of numerical fiscal rules, depending on the fiscal aggregate they concern. These are: public debt rules, balanced budget rules, expenditure rules and income rules. What is more, the rules in question have different characteristics with regard to the objective to be pursued by them, specific guidelines or transparency (Schaechter 2012).

Public debt rules set a clear limit or objective for public debt as a proportion of GDP (in\%). This type of fiscal rule is the most effective type of rule in terms of assurance of convergence with the debt purpose, and is relatively easy to communicate. However, achieving a specific objective takes time. The rule does not contain guidelines on how to implement fiscal policy in the short term. Public debt can be influenced by factors that go beyond the control of the government (change in interest rates, exchange rates, etc.). Moreover, fiscal policy can become pro-cyclical when the economy is affected by shocks and the public debt purpose continues to be binding. The budget balance rules limit the variable that primarily affects the debt ratio and is largely under the control of policy makers. Thus, such rules provide clear operational guidelines and can contribute to fiscal stability. Balanced budget rule may concern the general balance, structurally or cyclically adjusted balance, and the balance "throughout the cycle". Expenditure rules specify limits of total expenditures, current expenditures, or primary expenditures. Such limits are usually determined in absolute values, in terms of a rate (economic growth rate) and sometimes as a proportion of GDP. These rules are not directly linked to the goal of fiscal stability, until they also do not refer to the revenue side of the budget. Income / revenue rules set the maximum cap or (lower) income level and aim to increase the revenue collection or to prevent excessive tax burdens. Most of these rules are not directly related to the control of public debt, because they do not affect the expenditure reduction. Furthermore, setting the maximum cap or the minimum income level may be a significant challenge, as incomes may be significantly determined by the cyclical component. Exceptions are those rules that limit the use of additional "windfall" income in order to finance additional expenditures (cf. Schaechter et. al. 2012, Działo 2016).

Speaking of the functions of fiscal rules, the following issues can be mentioned (Walasik 2016):

- $\quad$ numeracy, comparability and independence from government fiscal policy;

- $\quad$ instrumentality which allows assessing of effectiveness of the implementation of fiscal policy goals;

- $\quad$ anti-cyclicality;

- planning nature;

- $\quad$ individualization which allows adjustment of the rule to the specificity of the public finance system of a given state.

Table 1. Properties of Different Types of Fiscal Rules 


\begin{tabular}{|l|l|l|}
\hline Type of rule & Pros & Cons \\
\hline Debt rule & $\begin{array}{l}\text { Direct link to debt sustainability } \\
\text { Easy to communicate and monitor }\end{array}$ & $\begin{array}{l}\text { No clear operational guidance in the short run as policy impact } \\
\text { on debt ratio is not immediate and limited } \\
\text { No economic stabilization feature } \\
\text { Rule could be met via temporary measures } \\
\text { Debt could be affected by developments outside the control of } \\
\text { the government }\end{array}$ \\
\hline $\begin{array}{l}\text { Budget balance } \\
\text { rule }\end{array}$ & $\begin{array}{l}\text { Clear operational guidance } \\
\text { Close link to debt sustainability } \\
\text { Easy to communicate and monitor }\end{array}$ & $\begin{array}{l}\text { No economic stabilization feature } \\
\text { Headline balance could be affected by developments outside } \\
\text { the control of the government (e.g., a major economic } \\
\text { downturn) }\end{array}$ \\
\hline $\begin{array}{l}\text { Structural } \\
\text { budget balance } \\
\text { rule }\end{array}$ & $\begin{array}{l}\text { Relatively clear operational guidance } \\
\text { Close link to debt sustainability } \\
\text { Economic stabilization function (i.e., } \\
\text { accounts for economic shocks) } \\
\text { Allows to account for other one-off and } \\
\text { temporary factors }\end{array}$ & $\begin{array}{l}\text { Correction for cycle is complicated, especially for countries } \\
\text { undergoing structural changes } \\
\text { Need to pre-define one-off and temporary factors to avoid their } \\
\text { discretionary use } \\
\text { Complexity makes it more difficult to communicate and monitor }\end{array}$ \\
\hline $\begin{array}{l}\text { Expenditure } \\
\text { rule }\end{array}$ & $\begin{array}{l}\text { Clear operational guidance } \\
\text { Allows for economic stabilization } \\
\text { Steers the size of government } \\
\text { Relatively easy to communicate and } \\
\text { monitor }\end{array}$ & $\begin{array}{l}\text { Not directly linked to debt sustainability since no constraint on } \\
\text { revenue side } \\
\text { Could lead to unwanted changes in the distribution of spending } \\
\text { if, to meet the ceiling, shift to spending categories occurs that } \\
\text { are not covered by the rule }\end{array}$ \\
\hline Revenue rule & $\begin{array}{l}\text { Steers the size of government } \\
\text { Can improve revenue policy and } \\
\text { administration } \\
\text { Can prevent pro-cyclical spending } \\
\text { (rules constraining use of windfall } \\
\text { revenue) }\end{array}$ & $\begin{array}{l}\text { Not directly linked to debt sustainability since no constraint on } \\
\text { expenditure side (except rules constraining use of windfall } \\
\text { revenue) } \\
\text { No economic stabilization feature }\end{array}$ \\
\hline
\end{tabular}

Source: Schaechter et. al. 2012.

\section{Mechanism of implementing fiscal rules in EU - supranational and national level}

\subsection{The EU level (supranational level)}

In the European Union, the fiscal policy is a subject of independent decisions of each Member State. The effects of these decisions taken under the influence of individual socio-economic conditions of each state have significant implications for the macroeconomic situation of other Member States. In EU, substantially from the beginning of works on the shape of the monetary union, attention has been paid to the dangers of unstable fiscal policy. Already in the Delors Commission report of 1989 , there was a statement about the existence of large and permanent deficits in public finances which have an impact on the monetary policy and heavily burden it. (Jędrzejowicz, Kitala, Wronka 2009). In order to avoid the negative impact of unstable fiscal policy, postulated was introduction of fiscal rules which would set the limit for the deficit and the limit for the public debt.

Economic and Financial Affairs Council (ECOFIN) composed of the ministers of finance of Member States is the main body of the European Union responsible for the surveillance and coordination of fiscal policy at the transnational level. (Gajewski, Skiba 2010). The general mechanism for fiscal coordination at European level consists of several instruments such as: Maastricht Treaty (1992), Stability and Growth Pact (1997 and 2005), reforms of 2011 introduced in the form of regulations and directives (so called Six-Pack), reforms of 2013 (so called Two-Pack) and the Fiscal Pact (Treaty on Stability, Coordination and Governance - entered into force in January 2013 in 25 signatory countries).

Coordination of economic policy, including fiscal policy of Member States, was introduced by the Maastricht Treaty in connection with preparations for the adoption of the Euro (see Jędrzejowicz, Kitala, Wronka 2009). Article 126 of the Treaty on the Functioning of the European Union (ex article 104 TEC, 1992) in relation to Protocol No 12 to the TEC defines the excessive budget deficit procedure. It adopts the principle of avoiding excessive deficit and the competence of the European Commission to monitor the development of the budgetary position and the level of public debt. Therefore, there are two evaluation criteria: 
a) whether the ratio of the planned or actual budget deficit to gross domestic product (GDP) exceeds the reference value, unless:

- $\quad$ the above mentioned ratio gradually decreases and is close to the reference value;

- $\quad$ or exceedance of the reference value is exceptional and transitional and the ratio remains close to the reference value;

- b) whether the ratio of public debt to gross domestic product exceeds the reference value, unless the ratio is successively reduced and approaching the reference value at a satisfactory pace. The detailed procedure for the excessive deficit is specified in Protocol No. 12. In art. 1 of the Protocol, two reference levels were adopted: 1

- $3 \%$ in relation to the planned or actual budget deficit to gross domestic product in market prices;

- $60 \%$ in relation to the public debt to gross domestic product in market prices.

Convergence criteria set the conditions for entry into the Euro Area, but the Treaty itself does not contain rules that explicitly state how the Euro Area Member States should be mobilized to maintain a low deficit. They force reduction of the deficit before adopting Euro, but they do not solve the problem of excessive public debt after adoption of the common currency. For this reason, on June 17, 1997 the European Council approved the adoption of the Stability and Growth Pact (Gajewski, Skiba, 2010). Stability and Growth Pact consists of: 1) Resolution of the European Council dated June 17, 1997 on stability and growth (Amsterdam) 2; 2) Council Regulation (EC) No. 1466/97 dated July 7, 1997 on the strengthening of the surveillance of budgetary positions and the surveillance and coordination of economic policies 3 ; 3) Council Regulation (EC) No. 1467/97 dated July 7, 1997 on speeding up and clarifying the implementation of the excessive deficit procedure. ${ }^{4}$ Stability and Growth Pact sets the frameworks for fiscal policy coordination in the Member States. The European Council, the Council of the European Union and the European Commission oblige EU Member States to implement SGP rules in a direct and timely manner. The Pact contains preventive and deterrent (corrective) elements, while acknowledging the need to respect the medium-term objective (MTO). As part of the prevention, Member States are required to submit annual stability or convergence programs and take corrective measures to achieve the objectives set out in these programs. Council Regulation (EC) No. 1466/97, as an integral part of the Stability and Growth Pact, assumes that compliance with the medium-term objective close to balance or in surplus will allow Member States to control normal cyclical fluctuations, while maintaining the public finance sector deficit below the reference value amounting to $3 \%$ of GDP. Council Regulation (EC) No. 1055/2005 dated June 27, 2005 amending Regulation (EC) No. 1466/97 on the strengthening of the surveillance of budgetary positions and the surveillance and coordination of economic policies assume that each country has a differentiated medium-term objective which may deviate from the objective close to balance or in surplus. These objectives provide a safety margin in the event of exceedance of deficit ratio of $3 \%$ of GDP. In the analyzed regulation for the countries that have adopted Euro and countries included in ERM-2, set was a range between $1 \%$ of GDP and the equilibrium or surplus in the cyclically adjusted balance that should correspond to the MTO (Sarrat de Tramezaigues 2010).

Three years after the outbreak of the global financial crisis (in 2011), the European Parliament adopted a package of six legal acts concerning the economic management proposed by the European Commission. The so called "Six-Pack" constitutes a strengthening of the EU Stability and Growth Pact and is intended to prevent future crises of the scale as in Greece. The crisis in Greece, Ireland and Portugal has shown that the EU system of disciplining of public finances of the Member States is ineffective. SGP did not allow the possibility of taking effective actions when the deficit exceeded $3 \%$ of GDP or responding to public debt growth in EU states. Within the frameworks of the "Six-Pack", penalties were introduced for countries violating fiscal discipline and macroeconomic stability that could jeopardize the whole EU. It is therefore possible to take actions when the budget deficit exceeds $3 \%$ of GDP. If the public debt exceeds $60 \%$ of GDP, the country will be obliged to decrease the annual public debt by $1 / 20$ annually within three years. In case of failure, the country will participate in the excessive deficit procedure. The Council will recommend and set the time for taking corrective actions. Failure to do so may result in financial penalties. Euro Area Countries will also be required to pay a deposit of $0.2 \%$ of GDP. If the country does not regain budget stability, it will lose its deposit on the basis of sanctions (European Parliament 2014; European Commission 2014).

\footnotetext{
1 OJ EU C 83, 30.03.2010, Protocol (No 12) on the excessive deficit procedure.

2 OJ EU C 236, 08.02.1997, P.0001-0002.

3 OJ EU L 209, 08.02.1997, p. 1-5.

${ }^{4}$ OJ EU L 209, 08.02.1997, p. 6-11.
} 
In 2011, the European Commission also proposed two further regulations to strengthen budgetary surveillance in the Euro Area. This packet of reforms, so called "Two-Pack" entered into force in 2013. The new regulations enhance the transparency of budgetary decisions in the Euro Area starting with the budget cycle in 2014. The "Two-Pack" includes two regulations aimed at further deepening of economic integration and convergence between Euro Area Member States. It introduces a common budgetary period and common budgetary principles for Euro Area Member States. In particular:

- until April 30, the Euro Area Member States must publish their medium-term budgetary plans (stability programs) alongside their political priorities for economic growth and employment for the next 12 months (National Reform Programs) - until October 15, the Euro Area Member States must publish their budget projects for the following year.

- until December 31, the Euro Area Member States must adopt their budgets for the following year. What is important, the "Two-Pack" increases the sustainability of national budget processes/ procedures by obliging Member States to base their budgetary projects/ plans on independent macroeconomic forecasts (European Commission 2014).

The next regulation - the Treaty on Stability, Coordination and Governance (TSCG, signed in 2013 - the so-called fiscal pact), from January 2014, mandated that the medium-term budgetary objective be recorded in the national law and must be $0.5 \%$ of GDP in relation to the structural deficit (in exceptional circumstances, it may increase to $1 \%$ ). The Treaty also stipulates that automatic corrective mechanisms should be triggered in the event of violation of structural deficit limit (European Commission 2014).

\subsection{National level}

Apart from the general fiscal policy coordination mechanism at the European level, Member States use their own fiscal policy instruments to ensure the sustainability of public finances. These are national fiscal policy instruments, such as fiscal rules, independent fiscal institutions and medium-term budget planning frameworks. Researchers have been interested in the above instruments for at least tens of years. However, in the years 2008-2010, in the period of global financial crisis and instability of the public finance system, interest in these instruments significantly increased. A total of 67 different types of national fiscal rules, including 26 budget balance rules, 18 indebtedness rules, 17 expenditure rules and 6 income rules were functioning in EU-27 in 2008. Most Member States applied more than one rule. Only three countries, i.e. Cyprus, Malta and Greece, did not apply any fiscal rules in 2008. In stability and convergence programs developed in the years 2009-20101, due to the deepening of the public finance crisis in most EU Member States, included was information on changes in national fiscal rules. In relation to 2008, introduced were 19 new rules and reformed were 2, previously functioning ones (Ayuso-i-Casals 2010, p. 10). Additionally, the impact of fiscal rules was strengthened by introducing or reforming other institutions constituting the mechanism of national fiscal policy coordination. At present, all EU-28 Member States apply fiscal rules.

\section{State of public finance in EU-28}

The recent economic crisis has contributed to a significant deterioration in the state of public finances in many countries. In the years 2007-2015, the average public debt as a proportion of GDP increased from the level of $58.8 \%$ to $85 \%$ in the EU-28, whereas in the Euro Area (EU-19) respectively from $65 \%$ to $90.4 \%$. Detailed analysis of statistical data leads, however, to the conclusion that, in many cases, long before the economic crisis, the fiscal policy implemented in individual EU states was not a responsible policy. Data included in table 2 shows that in most EU states, actions taken within the frameworks of the fiscal policy in the years 2002-2015 did not lead to the maintenance of a stable budget. It can therefore be said that the economic downturn has only highlighted the existing problem of lack of sustainability of public finances and has further encouraged the search for other factors affecting the quality of this policy, primarily of a structural nature.

Table 2. Public finance sector balance in EU states as a proportion of GDP (in\%)

\begin{tabular}{|l|l|l|l|l|l|l|l|l|l|l|l|l|l|l|}
\hline & 2002 & 2003 & 2004 & 2005 & 2006 & 2007 & 2008 & 2009 & 2010 & 2011 & 2012 & 2013 & 2014 & 2015 \\
\hline EU-19 & $-2,7$ & $-3,2$ & $-3,0$ & $-2,6$ & $-1,5$ & $-0,6$ & $-2,2$ & $-6,3$ & $-6,2$ & $-4,2$ & $-3,6$ & $-3,0$ & $-2,6$ & $-2,1$ \\
\hline
\end{tabular}

\footnotetext{
1 Under the regulations contained in the preventive part of the Stability and Growth Pact, the Euro Area Member States prepare annual stability programs, while other EU Member States prepare convergence programs and later present them to the European Commission and the Council. Their goal is to ensure more rigorous budgetary discipline by surveillance and coordination of budgetary policy in the Euro Area and within the EU.
} 


\begin{tabular}{|c|c|c|c|c|c|c|c|c|c|c|c|c|c|c|}
\hline EU-28 & $-2,6$ & $-3,2$ & $-2,9$ & $-2,5$ & $-1,6$ & $-0,9$ & $-2,4$ & $-6,6$ & $-6,4$ & $-4,6$ & $-4,3$ & $-3,3$ & $-3,0$ & $-2,4$ \\
\hline EU -27 & $-2,6$ & $-3,2$ & $-2,9$ & $-2,5$ & $-1,6$ & $-0,9$ & $-2,4$ & $-6,6$ & $-6,4$ & $-4,6$ & $-4,3$ & $-3,3$ & $-3,0$ & $-2,4$ \\
\hline Belgium & $-0,1$ & $-0,1$ & $-0,1$ & $-2,5$ & 0,4 & $-0,1$ & $-1,0$ & $-5,6$ & $-3,8$ & $-3,8$ & $-4,1$ & $-2,6$ & $-3,1$ & $-2,5$ \\
\hline Bulgaria & $-1,2$ & $-0,4$ & 1,9 & 1,0 & 1,9 & 1,2 & 1,7 & $-4,3$ & $-3,1$ & $-2,0$ & $-0,8$ & $-1,5$ & $-5,5$ & $-1,7$ \\
\hline Czech Republic & $-6,5$ & $-6,7$ & $-2,8$ & $-3,2$ & $-2,4$ & $-0,7$ & $-2,2$ & $-5,8$ & $-4,7$ & $-3,2$ & $-4,2$ & $-1,5$ & $-1,9$ & $-0,6$ \\
\hline Denmark & 0,4 & 0,1 & 2,1 & 5,2 & 5,2 & 4,8 & 3,2 & $-2,7$ & $-2,5$ & \begin{tabular}{|l|}
$-1,9$ \\
\end{tabular} & \begin{tabular}{|l|}
$-3,8$ \\
\end{tabular} & \begin{tabular}{|l|}
$-0,8$ \\
\end{tabular} & 1,5 & $-1,7$ \\
\hline Germany & $-3,8$ & $-4,2$ & $-3,8$ & $-3,3$ & $-1,6$ & 0,2 & $-0,1$ & $-3,1$ & $-4,2$ & $-0,8$ & 0,1 & 0,0 & 0,3 & 0.7 \\
\hline Estonia & 0,3 & 1,7 & 1,6 & 1,6 & 2,5 & 2,4 & $-3,0$ & $-2,0$ & 0,2 & 1,1 & $-0,2$ & $-0,2$ & 0,7 & 0,1 \\
\hline Ireland & $-0,4$ & 0,4 & 1,4 & 1,6 & 2,9 & 0,2 & $-7,4$ & $-13,7$ & $-30,6$ & $-13,1$ & $-8,2$ & $-7,2$ & $-3,7$ & $-1,9$ \\
\hline Greece & $-4,8$ & $-5,6$ & $-7,5$ & $-5,2$ & $-5,7$ & $-6,5$ & $-9,8$ & $-15,7$ & $-10,9$ & $-9,6$ & \begin{tabular}{|l|}
$, 8,9$ \\
\end{tabular} & \begin{tabular}{|l|}
$-12,7$ \\
\end{tabular} & $-3,6$ & $-7,5$ \\
\hline Spain & $-0,3$ & $-0,3$ & $-0,1$ & 1,3 & 2,4 & 2,0 & $-4,5$ & $-11,1$ & $-9,6$ & $-9,6$ & $-10,6$ & $-7,1$ & $-6,0$ & $-5,1$ \\
\hline France & $-3,1$ & $-4,1$ & $-3,6$ & $-2,9$ & $-2,3$ & $-2,7$ & $-3,3$ & $-7,5$ & $-7,0$ & $-5,2$ & $-4,9$ & $-4,3$ & $-4,0$ & $-3,5$ \\
\hline Croatia & $-3,2$ & $-2,4$ & $-3,8$ & $-2,8$ & $-2,8$ & $-1,9$ & $-1,9$ & $-5,4$ & $-6,4$ & $-7,8$ & $-5,0$ & $-4,9$ & \begin{tabular}{|l|}
$-5,4$ \\
\end{tabular} & $-3,3$ \\
\hline Italy & $-3,1$ & $-3,6$ & $-3,5$ & $-4,4$ & $-3,4$ & $-1,6$ & $-2,7$ & $-5,5$ & $-4,5$ & $-3,7$ & $-3,0$ & $-3,0$ & $-3,0$ & $-2,6$ \\
\hline Cyprus & $-4,4$ & $-6,6$ & $-4,1$ & $-2,4$ & $-1,2$ & 3,5 & 0,9 & $-6,1$ & $-5,3$ & \begin{tabular}{|l}
$, 6,3$ \\
$-6,3$
\end{tabular} & $-6,4$ & $-5,4$ & $-8,8$ & $-1,1$ \\
\hline Latvia & $-2,3$ & $-1,6$ & $-1,1$ & $-0,4$ & $-0,6$ & $-0,7$ & $-4,4$ & $-9,2$ & $-8,2$ & $-3,5$ & \begin{tabular}{|l|}
$-1,3$ \\
\end{tabular} & $-1,0$ & $-1,6$ & $-1,3$ \\
\hline Lithuania & $-1,9$ & $-1,3$ & $-1,5$ & $-0,5$ & $-0,4$ & $-1,0$ & $-3,3$ & $-9,4$ & $-7,2$ & $-5,5$ & $-3,2$ & $-2,2$ & $-0,7$ & $-0,2$ \\
\hline Luxembour & 2,1 & 0,5 & $-1,1$ & 0,0 & 1,4 & 3,7 & 3,2 & $-0,7$ & $\begin{array}{l}1,2 \\
-0,8\end{array}$ & 0,2 & 0,0 & \begin{tabular}{|l}
$-2, \mathbf{L}$ \\
0,1
\end{tabular} & $\begin{array}{l}-0, I \\
1,5\end{array}$ & 1,6 \\
\hline Hungary & $-9,0$ & $-7,3$ & $-6,5$ & $-7,9$ & $-9,4$ & $-5,1$ & $-3,7$ & $-4,6$ & $-4,3$ & 4,3 & $-2,1$ & $-2,2$ & $-2,1$ & $-1,6$ \\
\hline Malta & $-5,7$ & $-9,0$ & $-4,6$ & $-2,9$ & $-2,7$ & $-2,3$ & $-4,6$ & $-3,7$ & $-3,5$ & $-2,7$ & $-3,3$ & \begin{tabular}{|l|}
$-2,8$ \\
\end{tabular} & $-2,1$ & $-1,4$ \\
\hline Netherlands & $-2,1$ & $-3,1$ & $-1,7$ & $-0,3$ & 0,5 & 0,2 & 0,5 & $-5,6$ & $-5,1$ & $-4,3$ & $-4,1$ & $-2,5$ & $-2,3$ & $-1,9$ \\
\hline Austria & $-0,7$ & $-1,5$ & $-4,4$ & $-1,7$ & $-1,5$ & $-0,9$ & $-0,9$ & $-4,1$ & $-4,5$ & $-2,5$ & $-2,6$ & \begin{tabular}{|l|}
$-1,5$ \\
\end{tabular} & $-2,7$ & $-1,0$ \\
\hline Poland & $-5,0$ & $-6,2$ & $-5,4$ & $-4,1$ & $-3,6$ & $-1,9$ & $-3,7$ & $-7,5$ & $-7,8$ & $-5,1$ & $-3,9$ & $-4,3$ & $-3,4$ & $-2,6$ \\
\hline Portugal & $-3,4$ & $-3,7$ & $-4,0$ & $-6,5$ & $-4,6$ & $-3,1$ & $-3,6$ & $-10,2$ & $-9,8$ & $-4,3$ & $-6,4$ & $-4,9$ & $-7,2$ & $-4,4$ \\
\hline Romania & $-2,0$ & $-1,5$ & $-1,2$ & $-1,2$ & $-2,2$ & $-2,9$ & $-5,7$ & $-9,0$ & $-6,8$ & $-5,5$ & $-3,0$ & $-2,3$ & $-0,8$ & $-0,8$ \\
\hline Slovenia & $-2,4$ & $-2,7$ & $-2,3$ & $-1,5$ & $-1,4$ & 0,0 & $\begin{array}{l}-0,1 \\
-1,9\end{array}$ & $-6,3$ & $-5,9$ & $\begin{array}{l}-0,6 \\
-6,4\end{array}$ & $-4,0$ & $-14,7$ & $-5,0$ & $-2,7$ \\
\hline Slovakia & $-8,2$ & $-2,8$ & $-2,4$ & $-2,8$ & $-3,2$ & $-1,8$ & $-2,1$ & $-8,0$ & $-7,5$ & $-4,8$ & $-4,5$ & $-2,8$ & $-2,7$ & $-2,7$ \\
\hline Finland & 4,2 & 2,6 & 2,5 & 2,9 & 4,2 & 5,3 & 4,4 & $-2,5$ & $-2,5$ & $\begin{array}{l}, 0,7 \\
-0,7\end{array}$ & \begin{tabular}{|l|}
$-1,8$ \\
\end{tabular} & $-2,1$ & $-3,2$ & $-2,8$ \\
\hline Sweden & $-1,3$ & $-1,0$ & 0,6 & 2,2 & 2,3 & 3,6 & 2,2 & $-0,7$ & 0,3 & 0,2 & $-0,6$ & $-1,1$ & $-1,6$ & 0,2 \\
\hline United Kingdom & $-2,1$ & $-3,5$ & $-3,5$ & $-3,4$ & $-2,8$ & $-2,8$ & $-5,0$ & $-11,4$ & $-10,0$ & $-7,6$ & $-6,1$ & $-5,8$ & $-5,7$ & $-4,3$ \\
\hline
\end{tabular}

Source: elaboration on the base: Eurostat,

http://appsso.eurostat.ec.europa.eu/nui/show.do?dataset=gov_10dd_edpt1\&lang=en (01.04.2017).

In the years 2002-2015, the budget deficit as a proportion of GDP in EU-28 fluctuated between $-0.9 \%$ (in 2007) to $-6.6 \%$ (in 2009), while in the Euro Area (EU-19) respectively between $-0.6 \%$ (in 2007) to $-6.3 \%$ (in 2009). Starting from year 2010, however, it began to gradually decrease. In 2009 , the majority of EU countries did not meet the nominal convergence criterion on the budget deficit, in 2015 only five.

In the analyzed period, only a few countries, i.e. Sweden, Luxembourg, Estonia and Germany could be positively distinguished. In contrast, the budgetary situation in the so called old European Union states, i.e. in Greece, Spain, France, Portugal and Great Britain and in adopted in 2004 - Croatia (table 2) should be negatively assessed. In 2015, 22 EU Member States reported a budget deficit lower than $-3 \%$. The lowest deficits were achieved by Czech Republic $(-0.6 \%)$, Lithuania $(-0.2 \%)$, Austria $(-1.0 \%)$, Romania $(-0.8 \%)$, while a small budget surplus was achieved by four states: Germany $(0.7 \%)$, Estonia $(0.1 \%)$, Luxembourg $(1.6 \%)$, Sweden $(0.2 \%)$.

The use of the budget deficit as a measure of sustainability of public finances in the EU has its drawbacks (more: Próchnik 2012). The level of public debt as a proportion of GDP can be considered a more objective measure of the state of public finances. It cannot be forgotten that only exceedance of the budget deficit over 3\% of GDP (until 2012) was subject to sanctions and correction mechanism, which in reality were often only a "dead" regulation. At the same time, it should be noted that compliance with the rule of budget deficit at the level of $3 \%$ of GDP did not automatically guarantee the fulfillment 
of two other rules concerning the medium-term budgetary balance and the amount of public debt (at the level of $60 \%$ of GDP). However, the country which maintained a budget deficit at the level of approx. $3 \%$ of GDP did not usually meet the remaining criteria mentioned above. At the same time (until 2012) it was not exposed to any sanctions for this reason (Wojtas, Stolarczyk, 2011). Consequently, from a country's point of view, it was important to maintain above all the annual deficit level below the reference value of the fiscal standard, even at the expense of some manipulations ${ }^{1}$. Whereas, the public debt could in principle be increased without restriction, without the consequences of imposing penal sanctions.

Table 3. Public finance sector debt in EU as a proportion of GDP (in\%)

\begin{tabular}{|c|c|c|c|c|c|c|c|c|c|c|c|c|c|c|}
\hline country & 2002 & 2003 & 2004 & 2005 & 2006 & 2007 & 2008 & 2009 & 2010 & 2011 & 2012 & 2013 & 2014 & 2015 \\
\hline$E U-19$ & 66,9 & 68,1 & 68,4 & 69,2 & 67,4 & 65,0 & 68,6 & 78,4 & 83,8 & 86,1 & 89,5 & 91,3 & 92,0 & 90,4 \\
\hline$E U-28$ & 60,3 & 61,8 & 62,1 & 62,6 & 61,4 & 58,8 & 62,0 & 74,4 & 79,9 & 82,4 & 85,2 & 87,1 & 86,7 & 85,0 \\
\hline$E U-27$ & 60,3 & 61,9 & 62,2 & 62,7 & 61,5 & 58,9 & 62,2 & 74,5 & 80,2 & 82,7 & 85,5 & 87,4 & 86,7 & 85,0 \\
\hline Belgium & 103,4 & 98,4 & 94,0 & 92,0 & 87,9 & 84 & 89,2 & 96,6 & 96,6 & 99,2 & 101,1 & 101,5 & 106,5 & $\begin{array}{l}105, \\
8\end{array}$ \\
\hline Bulgaria & 52,4 & 44,4 & 37,0 & 27,5 & 21,6 & 17,2 & 13,7 & 14,6 & 16,2 & 16,3 & 18,4 & 18,9 & 27,0 & 26,0 \\
\hline Czech Republic & 27,1 & 28,6 & 28,9 & 28,4 & 28,3 & 27,9 & 28,7 & 34,6 & 38,4 & 41,4 & 46,2 & 46,0 & 42,2 & 40,3 \\
\hline Denmark & 49,5 & 47,2 & 45,1 & 37,8 & 32,1 & 27,1 & 33,4 & 40,7 & 42,8 & 46,4 & 45,4 & 44,5 & 44,8 & 40,4 \\
\hline Germany & 60,7 & 64,4 & 66,2 & 68,6 & 68,0 & 65,2 & 66,8 & 74,6 & 82,5 & 80,0 & 81,0 & 78,4 & 74,9 & 71,2 \\
\hline Estonia & 5,7 & 5,6 & 5 & 4,6 & 4,4 & 3,7 & 4,5 & 7,1 & 6,7 & 6,1 & 9,8 & 10,0 & 10,7 & 10,1 \\
\hline Ireland & 31,8 & 31,0 & 29,4 & 27,2 & 24,6 & 24,9 & 44,2 & 64,4 & 91,2 & 104,1 & 117,4 & 123,7 & 105,2 & 78,6 \\
\hline Greece & 101,7 & 97,4 & 98,6 & 100 & 106,1 & 107,4 & 112,9 & 129,7 & 148,3 & 170,3 & 157,2 & 175,1 & 179,7 & $\begin{array}{l}177, \\
4\end{array}$ \\
\hline Spain & 52,6 & 48,8 & 46,3 & 43,2 & 39,7 & 36,3 & 40,2 & 54,0 & 61,7 & 70,5 & 86,0 & 93,9 & 100,4 & 99,8 \\
\hline France & 58,8 & 62,9 & 64,9 & 66,4 & 63,7 & 64,2 & 68,2 & 79,2 & 82,7 & 86,2 & 90,6 & 93,5 & 95,3 & 96,2 \\
\hline Croatia & 35,1 & 36,3 & 38,2 & 38,5 & 35,7 & 33,3 & 30,0 & 36,6 & 45,0 & 52,0 & 55,9 & 67,1 & 86,6 & 86,7 \\
\hline Italy & 105,4 & 104,1 & 103,7 & 105,7 & 106,3 & 103,3 & 106,1 & 116,4 & 119,3 & 120,7 & 127,0 & 132,6 & 131,9 & $\begin{array}{l}132, \\
3\end{array}$ \\
\hline Cyprus & 65,1 & 69,7 & 70,9 & 69,4 & 64,7 & 58,8 & 48,9 & 58,5 & 61,3 & 71,5 & 86,6 & 111,7 & 107,1 & $\begin{array}{l}107, \\
5\end{array}$ \\
\hline Latvia & 13,6 & 14,7 & 15 & 12,5 & 10,7 & 9,0 & 19,8 & 36,9 & 44,5 & 42,0 & 40,8 & 38,1 & 40,7 & 36,3 \\
\hline Lithuania & 22,2 & 21,0 & 19,3 & 18,3 & 17,9 & 16,8 & 15,5 & 29,3 & 37,8 & 38,3 & 40,5 & 39,4 & 40,5 & 42,7 \\
\hline Luxembourg & 6,3 & 6,2 & 6,3 & 6,1 & 6,7 & 6,7 & 14,4 & 15,5 & 19,5 & 18,7 & 21,7 & 23,1 & 22,7 & 22,1 \\
\hline Hungary & 55,9 & 58,6 & 59,5 & 61,7 & 65,9 & 67,0 & 73,0 & 79,8 & 82,2 & 82,1 & 79,8 & 79,2 & 75,7 & 74,7 \\
\hline Malta & 57,9 & 66,0 & 69,8 & 68,0 & 62,5 & 60,7 & 60,9 & 66,5 & 66,0 & 68,8 & 70,8 & 73,0 & 67,0 & 64,0 \\
\hline Netherlands & 50,5 & 52,0 & 52,4 & 51,8 & 47,4 & 45,3 & 58,5 & 60,8 & 63,4 & 65,7 & 71,3 & 73,5 & 67,9 & 65,1 \\
\hline Austria & 66,2 & 65,3 & 64,7 & 64,2 & 62,3 & 60,2 & 63,8 & 69,2 & 72,5 & 73,1 & 74,4 & 74,5 & 84,4 & 85,5 \\
\hline Poland & 42,2 & 47,1 & 45,7 & 47,1 & 47,7 & 45,0 & 47,1 & 50,9 & 54,9 & 56,2 & 55,6 & 57,0 & 50,2 & 51,1 \\
\hline Portugal & 56,8 & 59,4 & 61,9 & 67,7 & 69,4 & 68,4 & 71,7 & 83,7 & 94,0 & 108,2 & 124,1 & 129,0 & 130,6 & $\begin{array}{l}129, \\
0\end{array}$ \\
\hline Romania & 24,9 & 21,5 & 18,7 & 15,8 & 12,4 & 12,8 & 13,4 & 23,6 & 30,5 & 34,7 & 38,0 & 38,4 & 39,4 & 37,9 \\
\hline Slovenia & 27,8 & 27,2 & 27,3 & 26,7 & 26,4 & 23,1 & 22 & 35,2 & 38,7 & 47,1 & 54,4 & 71,7 & 80,9 & 83,1 \\
\hline Slovakia & 43,4 & 42,4 & 41,5 & 34,2 & 30,5 & 29,6 & 27,9 & 35,6 & 41,0 & 43,6 & 52,7 & 55,4 & 53,6 & 52,5 \\
\hline
\end{tabular}

\footnotetext{
1 The countries may, e.g. use one-off operations on the income side (through tax changes) and on the expenditure side so that, at the time of evaluation, within one year, the requirement of a budget deficit below 3\% of GDP is met (Wojtas, Stolarczyk, 2011).
} 


\begin{tabular}{|l|l|l|l|l|l|l|l|l|l|l|l|l|l|l|}
\hline Finland & 41,5 & 44,5 & 44,4 & 41,7 & 39,6 & 35,2 & 33,9 & 43,5 & 48,8 & 49,3 & 53,6 & 57,0 & 60,2 & 63,6 \\
\hline Sweden & 52,5 & 51,7 & 50,3 & 50,4 & 45,2 & 40,2 & 38,8 & 42,6 & 39,4 & 38,6 & 38,3 & 40,6 & 45,2 & 43,9 \\
\hline United Kingdom & 37,1 & 38,7 & 40,3 & 41,7 & 42,7 & 43,7 & 51,9 & 67,1 & 78,4 & 84,3 & 89,1 & 90,6 & 88,1 & 89,1 \\
\hline
\end{tabular}

Source: elaboration on the base: Eurostat,

http://ec.europa.eu/eurostat/tgm/table.do?tab=table\&init=1\&language=en\&pcode=teina225\&plugin=1 (01.04.2017).

Data included in table 3 shows that in the years 2002-2015, the European Union as a whole, currently counting 28 members, met the criterion of public debt below $60 \%$ of GDP only in 2007. In the case of the Euro Area, however, in the years 20022015 , the debt below the reference value was unfortunately not reported. In 2002, proportion of debt to GDP in EU-19 was $66.9 \%$, in 2015 it exceeded the limit of $90 \%$ of GDP. In 2015, only eleven states had public debt below the reference value of $60 \%$, including six from the Euro Area

Accumulation of budget deficits led to a high level of public debt in individual EU Member States. During the examined period, the problem of debt growth was felt by most member states of the community. In 2015 , the level of $100 \%$ public debt as a proportion of GDP was exceeded in five states: Greece (177.4\%), Italy (132.3\%), Portugal (129\%), Cyprus (107.5\%) and Belgium (105.8\%). The lowest rate of public debt as a proportion of GDP was reported in 2015 in Estonia $(10.1 \%)$, Bulgaria (26\%) and Luxembourg (22.1\%).

\section{Evaluation of the effectiveness of implementation of fiscal rules in EU-28}

Reference books identify features of effective fiscal rules, such as: precise determination of the fiscal aggregate including the formula, flexibility, responsiveness to changes in economic conditions, simplicity of design, compliance of rules with the objectives of fiscal and macroeconomic policy (See: Anderson and Minarik, 2006; Kopits, 2001, von Hagen, 2002). However, the question arises of whether these conditions can be considered universal and therefore - whether they are equally effective in every situation? Do these principles allow for achievement of a long-term balance? There is no research in the literature unequivocally confirming that fiscal rules significantly improve fiscal policy discipline. Many researchers explicitly state that some rules may strengthen the pro-cyclicality of fiscal policy, it especially applies to numerical rules. Such impact of numerical rules is indicated, among others, by Sørensen et. al. (2001). Whereas, Ayuso-i-Casals et. al. (2007), based on the conducted research concerning the fiscal rules applicable within EU in the years 1990-2015, claim that fiscal policy pro-cyclicality was affected by $50 \%$ of the numerical rules applied in the EU states, it especially applies to budget balance rules. Even higher percentage of the rules strengthening the pro-cyclicality of fiscal policy were rules of public debt (81\%) (Gajewski, Skiba 2010). At the same time, Ayuso-i-Casals et. al. (2007) claim that expenditure rules may have the anti-cyclical impact on fiscal policy. However, it should be borne in mind that their effectiveness can also be illusory, due to the possibility of circumvention by the so-called creative accounting which is emphasized, among others, by Milesi-Ferretti (2000). A tendency to circumvent the rule will be the higher the less transparent will be the rule, therefore the effectiveness of fiscal regulations to a large extent also depends on accountability and transparency of public finances. At the same time, the previous research shows that in countries with greater fiscal transparency it is easier to maintain the budget discipline and to control expenditure. It is confirmed by Alesina and Perotti (1996) and by Poterba and von Hagen (1999) who claim that "the higher level of (fiscal policy) transparency is associated with a lower budget deficit".

Analyzes focusing on European experience, and in particular on European fiscal norms, confirm only partial effectiveness of these rules. Researchers point out that, they indeed led to a reduction in a fiscal imbalance before entering EMU, however after 2001, the imbalance in many Euro Area states unfortunately deepened (Flores et. al., 2005). The same opinion is held by von Hagen, Hallet and Strauch (2001) who also point out the lack of a mechanism of exclusion from Euro Area even after exceedance of reference values specified in the Treaty and PSW, which significantly weakens European fiscal regulations.

Based on the previous considerations it can be stated that one of the conditions of effective functioning of fiscal rules is their proper construction, i.e. durability but also low susceptibility to change and enforceability. Therefore, fiscal rules should be equipped with certain features, in particular such as: adequate "strong" legal basis, adequate monitoring, mechanisms allowing for effective enforcement and sanctions for non-compliance; clarity

The effectiveness of fiscal rules in enhancing fiscal discipline in the EU-28 countries may be evaluated using the fiscal rule index (FRI) prepared by ECOFIN which takes into account the above information for each rule, creating an index of "strength" for a particular rule (reflecting the strengths and the scope of impact of particular types of rules) and after a 
proper summation and grouping it creates the fiscal rule index for a given country in a given year (https://ec.europa.eu/info/business-economy-euro/indicators-statistics/economic-databases/fiscal-governance-eu-

member-states/numerical-fiscal-rules-eu-member-countries_en). In 2015 and at the beginning of 2016, a new, improved indexing methodology was used. An update of fiscal rule base took place and a "new" index may be used from 2015. Indexes are prepared based on data from surveys conducted by the European Commission. The following listed criteria are taken into account to construct the national fiscal rule indexes according to the old methodology: legal basis of the rule, the entity responsible for setting or changing the objectives, the authority responsible for monitoring compliance and enforcement of the rule, enforcement mechanisms, transparency of the application of the rule (role of the media).

A higher index indicator means a higher quality of fiscal rules (their higher restrictiveness) applicable in a particular country and should therefore point to a better public finance situation. However, due to differences in construction of individual rules in Member States, the FRI index should be interpreted with some caution. The fiscal crisis in the EU states resulted in a modification of the method of constructing of fiscal rule index because it was noted that the effectiveness of the rules (their compliance/ respect) depends to a large extent on their institutional characteristics. According to the new methodology (European Commission 2017) the following is taken into account: the legal basis of the fiscal rule, binding nature, monitoring and enforcement bodies, corrective mechanisms, resistance to shocks.

Conducting a comparative analysis of indexes calculated according to the new methodology is currently difficult because the available data only cover the year 2015. Thus, shaping of the fiscal rule index in the EU-28 states in the years 20022015 was shown according to the "old methodology": (Table 4).

Table 4. Fiscal rule index in EU-28 states according to the "old methodology"

\begin{tabular}{|c|c|c|c|c|c|c|c|c|c|c|c|c|c|c|}
\hline Country & 002 & 2003 & 2004 & 2005 & 2006 & 2007 & 2008 & 2009 & 2010 & 2011 & 2012 & 2013 & 2014 & 2015 \\
\hline Austria &, 10 & 0,10 & 0,10 & 0,00 & 0,00 & 0,00 & $-0,04$ & 0,26 & 0,26 & 0,34 & 0,51 & 0,51 & 0,51 & 0,49 \\
\hline Belgium & 0,04 & 0,04 & 0,04 & 0,04 & 0,04 & 0,04 & 0,04 & 0,04 & 0,04 & 0,04 & 0,07 & 0,07 & 1,54 & 1,54 \\
\hline Bulgaria &, 96 & 0,78 & 0,78 & 0,82 & 1,34 & 1,34 & 1,34 & 1,34 & 1,34 & 1,75 & 2,03 & 2,03 & 3,87 & 4,10 \\
\hline Cyprus & 89 & $-0,89$ & $-0,89$ & $-0,89$ & $-0,89$ & $-0,89$ & $-0,89$ & 0,89 & $-0,89$ & $-0,89$ & $-0,89$ & 0,65 & 0,95 & 0,95 \\
\hline Czech Republic & $-0,96$ & $-0,96$ & $-0,54$ & $-0,11$ & $-0,11$ & $-0,11$ & $-0,11$ & $-0,31$ & $-0,31$ & $-0,31$ & $-0,31$ & $-0,31$ & $-0,31$ & 0,31 \\
\hline Denmark & 1,05 & 1,05 & 1,05 & 1,05 & 1,05 & 0,94 & 0,94 & 0,94 & 0,94 & 0,09 & $-0,58$ & 1,04 & 1,56 & 1,56 \\
\hline Germ & 0,33 & 0,33 & 0,33 & 0,33 & 0,33 & 0,33 & 0,33 & 0,99 & 0,62 & 1,06 & 1,06 & 2,90 & 2,90 & 2,90 \\
\hline Estonia & 0,74 & 0,74 & 0,74 & 0,74 & 0,74 & 0,74 & 0,74 & 0,74 & 0,86 & 0,86 & 0,41 & 0,72 & 1,26 & 1,26 \\
\hline Greece & $\begin{array}{l}-0,96 \\
\end{array}$ & $-0,96$ & $-0,96$ & $-0,96$ & $\begin{array}{l}-0,96 \\
\end{array}$ & $-0,96$ & \begin{tabular}{|l|}
$-0,96$ \\
\end{tabular} & $-0,96$ & $-0,96$ & $-0,96$ & 0,66 & 0,66 & 0,77 & 0,77 \\
\hline Spain & 1,08 & 1,27 & 1,27 & 1,27 & 1,13 & 1,13 & 1,13 & 1,13 & 1,13 & 1,94 & 2,53 & 2,53 & 2,87 & 2,91 \\
\hline Finland & 0,63 & 0,60 & 0,60 & 0,60 & 0,60 & 0,60 & 0,27 & $-0,06$ & $-0,06$ & 0,07 & 0,04 & 1,37 & 1,34 & 1,34 \\
\hline France & $\begin{array}{l}-0,25 \\
\end{array}$ & $-0,25$ & $-0,25$ & $-0,25$ & 0,08 & 0,08 & 0,35 & 0,69 & 0,50 & 1,17 & 1,17 & 3,04 & 2,90 & 3,03 \\
\hline Croatia & $-0,96$ & $-0,96$ & $-0,96$ & $-0,96$ & $-0,96$ & $-0,96$ & $-0,96$ & 0,12 & 0,12 & 1,55 & 1,55 & 1,55 & 1,55 & 0,47 \\
\hline Hung & $-0,75$ & $-0,75$ & $-0,75$ & $-0,75$ & $-0,75$ & 0,33 & 0,33 & 0,10 & 0,10 & 0,10 & $-0,96$ & $-0,23$ & 1,82 & 1,91 \\
\hline $\begin{array}{l}\text { Ireland } \\
\end{array}$ & $\begin{array}{l}-0,94 \\
\end{array}$ & $-0,94$ & $-0,76$ & $-0,76$ & $-0,76$ & $-0,76$ & \begin{tabular}{|l|}
$-0,76$ \\
\end{tabular} & $-0,76$ & $-0,76$ & $-0,76$ & $-0,76$ & 2,08 & 2,08 & 1,95 \\
\hline Italy & 0,30 & 0,30 & 0,30 & 0,30 & 0,30 & 0,09 & 0,07 & 0,15 & 0,19 & 0,22 & 0,22 & 0,26 & 3,50 & 3,53 \\
\hline Lithuania & $-0,10$ & $-0,10$ & $-0,10$ & $-0,10$ & $-0,04$ & $-0,04$ & 0,51 & 0,51 & 0,51 & 0,51 & 0,53 & 0,53 & 0,53 & 3,09 \\
\hline Luxembour & 0,48 & 0,48 & 1,17 & 1,17 & 1,17 & 1,17 & 1,17 & 1,17 & 0,69 & 0,69 & 0,70 & 1,06 & 1,82 & 2,00 \\
\hline Latvia & $\begin{array}{l}-0,38 \\
\end{array}$ & $-0,38$ & $-0,38$ & $-0,38$ & $\begin{array}{l}-0,38 \\
\end{array}$ & $\begin{array}{l}-0,38 \\
\end{array}$ & \begin{tabular}{|l|}
$-0,38$ \\
\end{tabular} & $-0,38$ & $-0,38$ & $\begin{array}{l}-0,38 \\
\end{array}$ & $-0,38$ & 2,03 & 2,93 & 2,93 \\
\hline Malt & 96 & $-0,96$ & $-0,96$ & $-0,96$ & $-0,96$ & $-0,96$ & $-0,96$ & $-0,96$ & $-0,96$ & $-0,96$ & $-0,96$ & $-0,96$ & 1,92 & 1,92 \\
\hline Neth & 0,44 & 0,44 & 0,44 & 0,44 & 0,44 & 0,44 & 0,44 & 0,44 & 0,44 & 0,44 & 0,51 & 0,51 & 2,82 & 2,76 \\
\hline Poland & 0,73 & 0,73 & 0,73 & 0,73 & 1,41 & 1,41 & 0,73 & 1,09 & 1,09 & 1,41 & 1,38 & 1,23 & 1,52 & 2,13 \\
\hline Portugal & $-0,39$ & $-0,25$ & $-0,25$ & $-0,25$ & $-0,25$ & $-0,21$ & $-0,21$ & $-0,21$ & $-0,21$ & $-0,21$ & $-0,07$ & 1,37 & 1,49 & 2,43 \\
\hline Romania & $-0,48$ & $-0,48$ & $-0,48$ & $-0,48$ & $-0,48$ & $-0,48$ & $-0,48$ & $-0,48$ & $-0,48$ & $-0,48$ & $-0,48$ & $-0,48$ & 2,84 & 2,84 \\
\hline Sweden & 1,15 & 1,15 & 1,15 & 1,15 & 1,15 & 1,28 & 1,28 & 1,28 & 1,39 & 1,39 & 1,39 & 1,39 & 1,39 & 1,39 \\
\hline & 96 & $-0,96$ & $-0,96$ & $-0,96$ & $-0,96$ & $-0,96$ & $-0,96$ & $-0,96$ & $-0,96$ & $-0,96$ & $-0,96$ & $-0,96$ & $-0,96$ & 0,96 \\
\hline & 0, & 0,00 & 0,00 & 0,00 & 0,00 & 0,00 & 0,00 & $-0,03$ & $-0,03$ & $-0,03$ & 1,81 & 1,81 & 2,52 & 2,52 \\
\hline United Kin & 1,38 & 1,38 & 1,38 & 1,38 & 1,38 & 1,38 & 1,38 & $-0,96$ & 1,13 & 1,09 & 1,09 & 1,09 & 1,17 & 0,53 \\
\hline
\end{tabular}

Source: https://ec.europa.eu/info/publications/fiscal-rules-database_en (15.04.2017). 
The analysis of the fiscal rule indices presented in Table 4 shows a relatively high quality of fiscal rules (restrictiveness) at the end of the research period (2015) in countries such as: Bulgaria, Germany, Spain, France, Italy, Lithuania, Luxembourg, Latvia, Netherlands, Poland. Portugal, Romania and Slovakia. Much less restrictive rules were applied in Austria, Czech Republic, Croatia, Slovenia and the United Kingdom.

\section{Figure 1. Fiscal Rule Index}

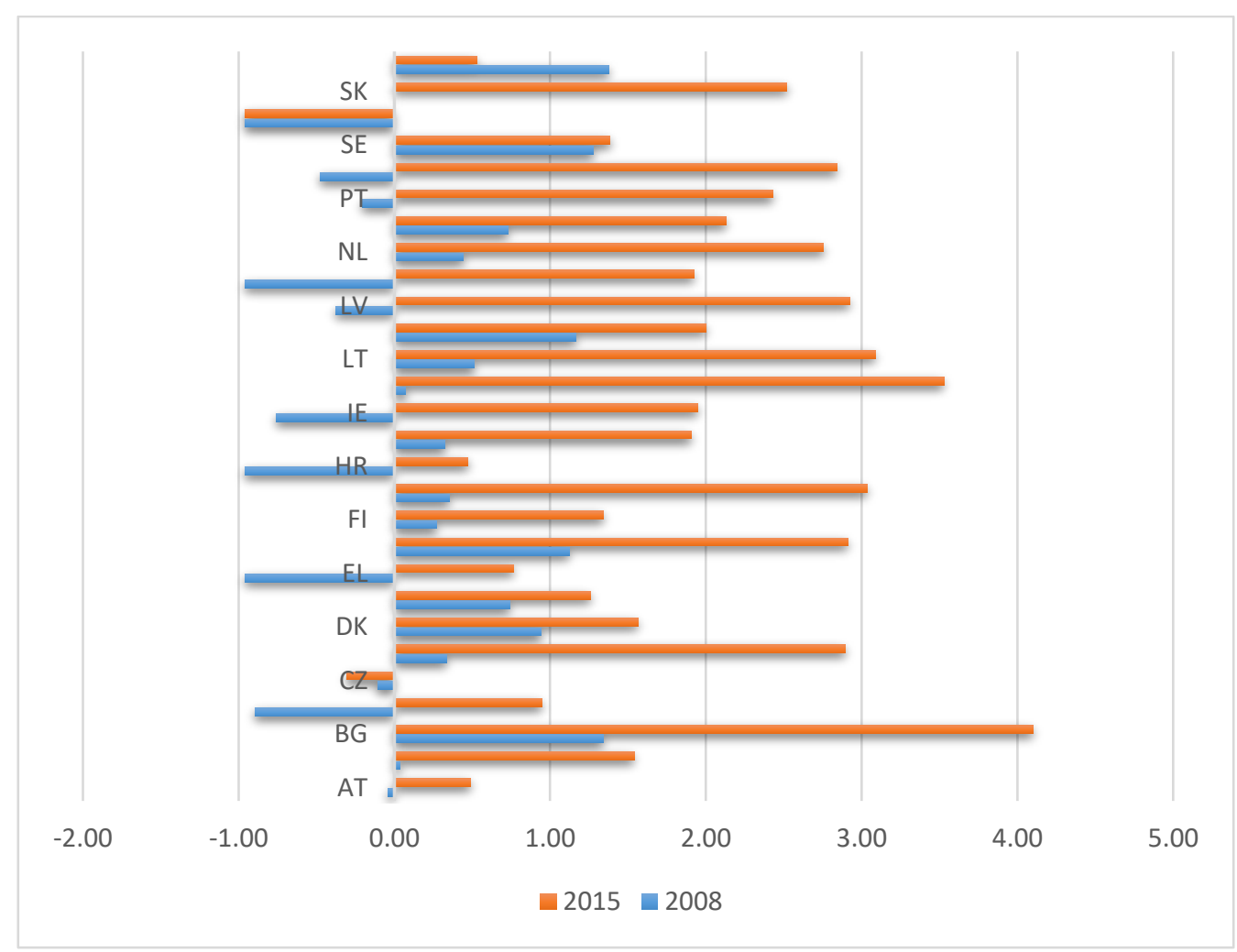

Source: Own eleboration.

The general trend is improvement of fiscal rule indices in almost all countries beginning from 2008, which can be explained by an attempt to respond to the global financial crisis (Figure 1). Moreover, the reforms introduced in the sphere of fiscal policy coordination at EU level in the years 2011-2013 were undoubtedly affecting this situation. Compared to 2008, the value of the fiscal rule index did not change only in Slovenia, and decreased only in the UK. The biggest increase in the value of fiscal rule index during the years 2008-2015 took place in Bulgaria from 1.34 to 4.10; in Germany from 0.33 to 2.90; in Romania from -0.48 to 2.84 ; in France from 0.35 to 3.03 ; in Italy from 0.07 to 3.53 ; in Lithuania from 0.51 to 3.09 ; in Latvia from -0.38 to 2.93; in Malta from -0.96 to 1.92; in Holland from 0.44 to 2.76; in Portugal from -0.21 to 2.43 ; in Slovakia from 0.00 to 2.52 .

Table 5. Fiscal rule index as well as the level of budget deficit and public debt in years 2002 and 2015

\begin{tabular}{|l|l|l|l|l|l|l|}
\hline \multirow{3}{*}{ Country } & FRI & Deficit & Public_Debt \\
\cline { 2 - 7 } & 2002 & 2015 & 2002 & 2015 & 2002 & 2015 \\
\hline Austria & 0,10 & 0,49 & $-1,4$ & $-1,0$ & 66,50 & 85,5 \\
\hline Belgium & 0,04 & 1,54 & 0,0 & $-2,5$ & 104,70 & 105,8 \\
\hline Bulgaria & $-0,96$ & 4,10 & $-1,2$ & $-1,7$ & 51,40 & 26 \\
\hline
\end{tabular}




\begin{tabular}{|l|l|l|l|l|l|l|}
\hline Cyprus & $-0,89$ & 0,95 & $-4,1$ & $-1,1$ & 59,70 & 107,5 \\
\hline Czech Republic & $-0,96$ & $-0,31$ & $-6,3$ & $-0,6$ & 25,90 & 40,3 \\
\hline Denmark & 1,05 & 1,56 & 0,0 & $-1,7$ & 49,10 & 40,4 \\
\hline Germany & 0,33 & 2,90 & $-3,9$ & 0,7 & 59,40 & 71,2 \\
\hline Estonia & 0,74 & 1,26 & 0,4 & 0,1 & 5,70 & 10,1 \\
\hline Greece & $-0,96$ & 0,77 & $-6,0$ & $-7,5$ & 104,90 & 177,4 \\
\hline Spain & 1,08 & 2,91 & $-0,4$ & $-5,1$ & 51,30 & 99,8 \\
\hline Finland & 0,63 & 1,34 & 4,1 & $-2,8$ & 40,20 & 63,6 \\
\hline France & $-0,25$ & 3,03 & $-3,1$ & $-3,5$ & 60,00 & 96,2 \\
\hline Croatia & $-0,96$ & 0,47 & $-3,5$ & $-3,3$ & 36,60 & 86,7 \\
\hline Hungary & $-0,75$ & 1,91 & $-8,8$ & $-1,6$ & 55,00 & 74,7 \\
\hline Ireland & $-0,94$ & 1,95 & $-0,3$ & $-1,9$ & 30,60 & 78,6 \\
\hline Italy & 0,30 & 3,53 & $-3,1$ & $-2,6$ & 101,90 & 132,3 \\
\hline Lithuania & $-0,10$ & 3,09 & $-1,9$ & $-0,2$ & 22,10 & 42,7 \\
\hline Luxembourg & 0,48 & 2,00 & 2,5 & 1,6 & 6,90 & 22,1 \\
\hline Latvia & $-0,38$ & 2,93 & $-2,2$ & $-1,3$ & 13,10 & 36,3 \\
\hline Malta & $-0,96$ & 1,92 & $-5,4$ & $-1,4$ & 63,20 & 64 \\
\hline Netherlands & 0,44 & 2,76 & $-2,1$ & $-1,9$ & 48,50 & 65,1 \\
\hline Poland & 0,73 & 2,13 & $-4,8$ & $-2,6$ & 41,80 & 51,1 \\
\hline Portugal & $-0,39$ & 2,43 & $-3,3$ & $-4,4$ & 56,20 & 129 \\
\hline Romania & $-0,48$ & 2,84 & $-1,9$ & $-0,8$ & 24,80 & 37,9 \\
\hline Sweden & 1,15 & 1,39 & $-1,5$ & 0,2 & 50,20 & 43,9 \\
\hline Slovenia & $-0,96$ & $-0,96$ & $-2,4$ & $-2,7$ & 27,30 & 83,1 \\
\hline Slovakia & 0,00 & 2,52 & $-8,1$ & $-2,7$ & 42,90 & 52,5 \\
\hline United Kingdom & 1,38 & 0,53 & $-4,3$ & 89,1 & 34,70 & 89,10 \\
\hline Soure: Own & & & & & \\
\hline
\end{tabular}

Source: Own elaboration

Analysis of the data presented in Table 5 does not provide unambiguous results, as in the group of countries that have a relatively good budgetary situation, the value of the fiscal index can be both high and low. Symptomatic is fact that in countries where public debt exceeded the level of $100 \%$ of GDP, the value of the fiscal rule index is relatively high. It seems that only analysis of institutional characteristics of the individual countries would allow for drawing unequivocal conclusions. Moreover, the evaluation of change of the level of such a fiscal aggregation as the public debt is possible in the long horizon.

\section{Conclusion}

Review of literature and the experience of European countries show that different types of fiscal rules are not equally effective in reducing the fiscal imbalance, however if well constructed they can, along with other budgetary institutions, support measures aiming to reduce the public debt and reduce the fiscal policy pro-cyclicality. National fiscal rules, in case of strong legal bases and built-in enforcement mechanisms, can undoubtedly contribute to the improvement of public finance situation. It should however be emphasized that the fiscal rules in EU-28 states have different institutional characteristics, hence the assessment of their effectiveness implies certain difficulties. Based on the analysis of fiscal indices in the period of 2002-2015 in different EU Member States, it may be concluded that the value of the reviewed index increased in 26 of them. Its decrease was reported only in the United Kingdom, whereas it did not change only in Slovenia. Comparison of the values of the fiscal rule index with the budgetary performance (budget deficit and public debt level) shows that its high level is not correlated with the low level of public debt, with a more visible positive influence on the budget deficit level. To sum up, it is worthwhile to conduct further studies on the quality of fiscal rules, their institutional characteristics and to analyze their effectiveness in increasing fiscal discipline. Nevertheless, it should be borne in mind that due to macroeconomic conditions and delays in time, the connection between fiscal sustainability and the high fiscal rule index is not obvious. 


\section{References}

[1] Alesina, A., Perotti, R. (1996). Budget deficit and budget institutions, IMF Working Paper WP/52.

[2] Alesina, A., Perotti, R. (1996). Fiscal Discipline and the Budget Process, American Economic Review, No. 2.

[3] Alesina, A., Perotti, R. (1994). Political economy of budget deficits, NBER Working Paper, No. 4637.

[4] Ayuso-i-Casals J., Debrun X., Kumar M. S., Moulin L., Turrini A. (2007). Beyond the SGP - Features and effects of EU national-level numerical fiscal rules, http://www.cepr.org/meets/wkcn/9/973/papers/ayuso_etal.pd.

[5] Ayuso-i-Casals, J.(2010). National fiscal governance reforms across EU Member States. Analysis of the information contained in the 2009-2010 Stability and Convergence Programmes, European Commission.

[6] Babczuk, A. (2007). Procedura budżetowa a nierównowaga fiskalna - wybrane problemy, [in:] Polityka gospodarcza państwa, D. Kopycińska (ed.), Wydawnictwo Mikroekonomii Uniwersytetu Szczecińskiego, Szczecin.

[7] Brzozowski, M. et.al. (2006). Instytucje a polityka makroekonomiczna i wzrost gospodarczy, Uniwersytet Warszawski Wydział Nauk Ekonomicznych, Warszawa.

[8] Council Regulation ( EC ) No 1466/97 of 7 July 1997 on the strengthening of the surveillance of budgetary positions and the surveillance and coordination of economic policies, OJ EU L 209, 08.02.1997, p. 1-5.

[9] Debrun, X., Hauner, D., Kumar, M.S. (2008). Independent fiscal agencies, Journal of Economic Surveys, Vol. 23.

[10] Działo, J. (2016). Indeks reguł fiskalnych jako miara jakości reguł fiskalnych w Unii Europejskiej, Studia PrawnoEkonomiczne, Vol. XCIX.

[11] European Commission, http://appsso.eurostat.ec.europa.eu/nui/show.do?dataset=gov_10dd_edpt1\&lang=en

[12] European Commission, http://ec.europa.eu/eurostat/tgm/table.do?tab=table\&init=1\&language=en\&pcode=teina225\&plugin=1

[13] European Commission, https://ec.europa.eu/info/publications/fiscal-rules-database_en

[14] Flores E., Giudice, G., Turrini, A. (2005). The framework for fiscal policy in EMU: What future after five years of experience? European Economy, Economic Papers No. 223.

[15] Franek, S. (2016). Trwałość reguł fiskalnych jako kryterium wiarygodności fiskalnej https://www.obserwatorfinansowy.pl/forma/rotator/trwalosc-regul-fiskalnych-jako-kryterium-wiarygodnosci-fiskalnej/

[16] Gajewski, P., Skiba, L. (2010). Problemy polityki fiskalnej Polski na drodze do strefy euro w kontekście uwarunkowań i doświadczeń innych państw, NBP, Warszawa.

[17] Gołębiowski, G. (2010). Rada Polityki Fiskalnej, Biuro Analiz Sejmowych, Infos No. 9.

[18] https://ec.europa.eu/info/business-economy-euro/indicators-statistics/economic-databases/fiscal-governance-eumember-states/numerical-fiscal-rules-eu-member-countries_en

[19] Jędrzejowicz, T., Kitala, M., Wronka, A. (2009). Polityka fiskalna w kraju należącym do strefy euro. Wnioski dla Polski. www.nbp.pl/badania/seminaria_bise/jedrzejowiczO.pdf

[20] Kopits G. (2007). Fiscal Responsibility Framework: International Experience and Implications for Hungary, MNB Occasional Papers No. 62.

[21] Kopits, G., Symansky, S. (1998). Fiscal policy rules, International Monetary Fund, Occasional Paper No. 162, Washington.

[22] Lane, P.R. (2010). A new fiscal framework for Ireland, IIIS Discussion Paper, No. 315.

[23] Lienert, I. (2010). Should Advanced Countries Adopt a Fiscal Responsibility Law?, International Monetary Fund Working Paper WP/10/254.

[24] Marchewka-Bartkowiak, K. (2010). Reguły fiskalne, Analizy BAS, No. 7.

[25] Milesi-Ferretti ,G.M. (2000), Good, Bad or Ugly? On the Effects of Fiscal Rules with Creative Accounting, CEPR Discussion Papers No 2663, http://www.cepr.org/pubs/dps/DP2663.asp.

[26] Official Journal of the European Union, Consolidated Versions of the Treaty on European Union and the Treaty on the Functioning of the European Union; Protocol (No 12) on the excessive deficit procedure, OJ EU C 83, 30.03.2010.

[27] Perotti, R., Kontopoulos, Y.(2002). Fragmented fiscal policy, Journal of Public Economics, Vol. 82.

[28] Pierwszy pakiet reform dla konsolidacji finansów publicznych. Propozycje dla Prezydenta RP (2010). Ministerstwo Finansów, Warszawa.

[29] Poterba, J. M., von Hagen, J. (1999). Fiscal Institutions and Fiscal Performance, University of Chicago Press, NBER, http://www.nber.org/chapters/c8020.pdf.

[30] Report on Public finances in EMU 2016, EC, https://ec.europa.eu/info/publications/economy-finance/report-publicfinances-emu-2016-0_en 
[31] Resolution of the European Council on the Stability and Growth Pact (Amsterdam, 17 June 1997), OJ EU C 236, 08.02.1997, P.0001-0002.

[32] Schaechter, A., Kinda, T., Budina, N., Weber A. (2012). Fiscal Rules in Response to the Crisis-Toward the "NextGeneration" Rules. A New Dataset, WP/12/187.

[33] Sørensen, B. E., Wu L., Yosha, O. (2001). Output fluctuations and fiscal policy: U.S. state and local governments 1978-1994, European Economic Review, No. 45.

[34] von Hagen, J., Harden, I. (1995). Budget process and commitment to fiscal discipline, European Economic Review, Vol. 39.

[35] Walasik, A. (2016). Reguły fiskalne zarządzania finansami publicznymi, Studia BAS, No. 3(47). 